\title{
Role of chromatin assembly factor-1/p60 and poly [ADP-ribose] polymerase 1 in mycosis fungoides
}

\author{
Massimo Mascolo ${ }^{1} \cdot$ Antonio Travaglino $^{1} \cdot$ Silvia Varricchio $^{1} \cdot$ Daniela Russo $^{1} \cdot$ Elena Sabattini $^{2} \cdot$ Claudio Agostinelli $^{2}$. \\ Clara Bertuzzi $^{2} \cdot$ Antonello Baldo $^{3} \cdot$ Alessandro Pileri $^{4} \cdot$ Marco Picardi $^{5} \cdot$ Fabrizio Pane $^{5} \cdot$ Stefania Staibano $^{1}$
}

Received: 30 July 2020 / Revised: 16 September 2020 / Accepted: 14 October 2020 / Published online: 24 October 2020

(C) The Author(s) 2020

\begin{abstract}
Mycosis fungoides (MF) represents the most common type of cutaneous lymphoma. In the majority of patients, the disease has a slow evolution and a protracted course; however, a subset of patients shows poor oncologic outcomes. Unfortunately, there are no reliable prognostic markers for MF, and the currently available treatments are only effective in a minority of patients. This study aimed to evaluate the expression and clinical significance of PARP-1 and CAF-1/p60 in MF. Sixty-four MF representatives of the different stages of disease were assessed by immunohistochemistry for PARP-1 and CAF-1/p60. The association of PARP-1 and CAF-1/p60 with the MF stage and outcome was assessed by using Fisher's exact test and Kaplan-Meier survival analysis with the Log-rank test; a $p$ value $<0.05$ was considered significant. PARP-1 was overexpressed in $57.9 \%$ of MF and was significantly associated with a MF stage $>$ II $(p=0.034)$ but not with the risk of death $(p=0.237)$. CAF-1/p60 was overexpressed in $26.8 \%$ of MF and was significantly associated with decreased overall survival $(p<0.001)$ but not with the MF stage $(p=1)$. A significant association was found between PARP-1 overexpression and CAF-1/p60 overexpression $(p=0.0025)$. Simultaneous overexpression of PARP-1 and CAF-1/p60 was significantly associated with decreased overall survival $(p<0.001)$, although less strongly than CAF-1/p60 alone ( $\chi^{2}=14.916$ vs 21.729 , respectively). In MF, PARP-1 is overexpressed in advanced stages, while CAF-1/p60 is overexpressed in the cases with shorter overall survival, appearing as a significant prognostic marker. A role for PARP-1 inhibitors and anti-CAF-1/p60 targeted therapy may be reasonably hypothesized in MF.
\end{abstract}

Keywords Mycosis fungoides · Cutaneous lymphoma - Poly [ADP-ribose] polymerase 1 . Chromatin assembly factor-1 . Prognosis

Antonio Travaglino and Silvia Varricchio contributed equally to this work.

Electronic supplementary material The online version of this article (https://doi.org/10.1007/s00428-020-02952-z) contains supplementary material, which is available to authorized users.

Massimo Mascolo

massimo.mascolo@unina.it

1 Department of Advanced Biomedical Sciences, Pathology Section, School of Medicine, University of Naples "Federico II", Via Sergio Pansini, 5, 80131 Naples, Italy

2 Haematopathology Unit, Department of Experimental Diagnostic and Specialty Medicine, S. Orsola-Malpighi Hospital, University of Bologna, Bologna, Italy

3 Department of Clinical Medicine and Surgery, Dermatology Section, University of Naples "Federico II", Naples, Italy

4 Dermatology Unit, Department of Experimental, Diagnostic and Specialty Medicine, University of Bologna, Bologna, Italy

5 Department of Clinical Medicine and Surgery, Hematology Section, University of Naples "Federico II", Naples, Italy

\section{Abbreviations \\ MF Mycosis fungoides \\ PARP-1 Poly [ADP-ribose] polymerase 1 \\ CAF-1 Chromatin assembly factor-1 \\ CAF-1/p60 p60 subunit of CAF-1}

\section{Introduction}

Mycosis fungoides (MF) is the most common type of primary cutaneous lymphoma, accounting for about $50 \%$ of cases [1, 2]. The incidence of MF is nearly 5.6 person per million, with marked regional variations and a higher incidence in the Black population, in adults and elderly patients, and in males [3-6].

Clinically, MF is a multistep process moving from patches to more infiltrated plaques and, eventually, developing into tumors, with slow progression over the years or decades; less common clinical variants are also described [7, 8]. At 
advanced stages (IIB-IVB), the 10-year survival decreases to less than $40 \%[9,10]$. Few MF cases may undergo large cell transformation, characterized by an aggressive clinical course and a median survival of less than 2 years [11].

Treatment is often multidisciplinary, as it combines skindirected and systemic therapies [12]. However, targeted therapies achieve a complete response in less than half of patients, while conventional chemotherapy is associated with shortlived responses and worse overall outcomes [13-15]. The only potential cure for MF is traditional non-myeloablative allogeneic stem cell transplantation, which an overall survival rate of $46 \%$ at 5 years [15].

Patients with an advanced stage of the disease are associated with poor prognosis with a median survival $<4$ years, but of only 13 months in the presence of nodal involvement [16-20].

Although several prognostic markers have been studied in MF to identify early-stage cases at high risk of disease progression [21-24], to date none has been validated and integrated in the management of MF patients.

Recently, Lemchak et al. identified poly [ADP-ribose] polymerase 1 (PARP-1) as a possible prognostic biomarker in MF [25]. PARP-1 is a protein involved in DNA repair which has been used as a therapeutic target in several human cancers [26-28]. In the case of MF, patients with PARP-1 overexpression in the early phase of the disease subsequently progressed to advanced stages [25].

CAF-1 is a heterotrimeric protein complex formed of three subunits (p48, p60, and p150) [29-34]. The CAF-1/p60 subunit plays a crucial function in cell replication, and its deregulation is involved in several human solid malignancies [35-41]. Interestingly, CAF-1/p60 expression has been shown to have a prognostic significance in several human malignant tumors [42-49], appearing as a possible "multi-tumoral" prognostic marker.

We previously showed that a simultaneous overexpression of PARP-1 and CAF-1/p60 was a specific hallmark of aggressiveness in oral squamous cell carcinoma [46].

Until now, in the literature, no data are available about the expression of CAF-1/p60 in patients with MF, and, to our knowledge, the only study evaluating the expression of PARP-1 in MF evaluated only 19 cases [25]. On this account, we aimed to evaluate the prognostic significance of PARP-1 and CAF1/p60 in a selected series of MF at different stages of the disease.

\section{Materials and methods}

\section{Study population}

Formalin-fixed, paraffin-embedded (FFPE) tissue blocks of 64 MF biopsies (20 incisional biopsies and 44 punch biopsies), diagnosed from January 1994 to December 2019 and representative of different stages of the disease, were retrieved from the archives of the Department of Advanced Biomedical Sciences, Pathology Unit, University Federico II of Naples and Haematopathology Unit, Department of Experimental Diagnostic and Specialty Medicine, S. OrsolaMalpighi Hospital, University of Bologna. An expert panel of dermatologists ( $\mathrm{AB}$ and $\mathrm{AP})$ and pathologists (MM, DR, ES, and $\mathrm{CA}$ ) confirmed the diagnosis according to the criteria of the WHO-EORTC Classification of Cutaneous Lymphoma.

Follow-up data were retrospectively retrieved from clinical records and pathological reports. Overall survival (OS) was established from diagnosis to death or to the last contact date. Follow-up data included complete skin examination and laboratory tests for all patients; computed tomography scan of the chest, abdomen, and pelvis and bone marrow biopsy were performed on follow-up only if they were positive at the time of diagnosis.

The study was performed according to the guidelines of the Institutional Ethics Committee, which, in agreement with the Italian law, with reference to the topics of the current research, do not ask for the Ethical Committee approval, and, according to the Declaration of Helsinki, requires, for studies based only on retrospective analyses on routine archival FFPE tissue, a written informed consent from the living patient, following the indication of Italian DLgs no. 196/03 (Codex on Privacy) at the time of surgery.

\section{Immunohistochemistry}

Immunohistochemistry was performed as previously described [46]. Slides were evaluated blindly by four observers (MM, DR, ES, and CA) and the cases with discordance were discussed and resolved by consensus. In all cases, five fields (940 magnifications) were assessed, evaluating a minimum of 20 cells in the representative areas. The expression of PARP-1 and CAF- $1 / \mathrm{p} 60$ was quantified according to the percentage of stained nuclei using a $0-100 \%$ scale. The expression of PARP-1 and CAF-1/p60 was assessed to the nearest $10 \%$ to define the most significant threshold for the analysis. Since the most significant results were found for the $50 \%$ threshold, positivity in $\geq 50 \%$ of cells was labeled as "overexpression."

\section{Statistical analysis}

Statistical associations among PARP-1 expression, CAF-1/ p60 expression, and MF stage were assessed by using Fisher's exact test; a $p$ value $<0.05$ was considered significant. Kaplan-Meier survival analysis and log-rank test with $\chi^{2}$ calculation were used to assess the impact of PARP-1 and CAF-1/p60 expression on the OS, with a significant $p$ value $<0.05$; Kaplan-Meier curves were used to report the results graphically. Statistical analyses were performed by using 
Statistical Package for Social Science (SPSS) 18.0 package (SPSS Inc., Chicago, IL, USA).

\section{Results}

\section{Clinical and pathological parameters}

The clinical data and pathological features of the patients and MF are listed in Table 1. The study population was composed of 64 patients, out of which 43 males $(67.2 \%)$ and 21 females (32.8\%), with a mean age of 59.4 years (range 29-96 years).

Information about MF stage was available for 53 patients $(82.8 \%)$. MF stage was IA in 9 patients (17\%), IB in 11 patients (20.8\%), IIA in 7 patients (13.2\%), IIB in 13 patients (24.5\%), IIIA in 1 patient (1.9\%), IVA1 in 7 patients (13.2\%), and IVA2 in 5 patients $(9.4 \%) ; 12$ cases (18.8\%) showed large cell transformation.

PARP-1 resulted overexpressed in 33 cases (57.9\%), while CAF-1/p60 was overexpressed in 15 cases (26.8\%) (Figs. 1, 2, and 3). Among the 12 cases with large cell transformation, PARP-1 and CAF-1/p60 immunostaining was successful in 11/12 cases, out of which 10 (90.9\%) showed PARP-1 overexpression and 4 (36.4\%) showed CAF-1/p60 overexpression; remarkably, considering only the large cells, both PARP-1 and CAF-1/p-60 were overexpressed in all 11 cases (100\%).

A significant association was found between PARP-1 overexpression and CAF-1/p60 overexpression $(p=0.0025)$. PARP-1 was significantly associated with a MF stage $>$ II $(p=0.034)$, while CAF-1/p60 was not $(p=1)$.

Follow-up data were available for 63 patients (98.4\%); the mean follow-up duration was 52.9 months (range 12180 months). At the last follow-up, 8 patients were dead (12.7\%), 28 were alive with disease (44.4\%), 15 were alive with complete remission (23.8\%), and 6 were alive with unknown status of disease (19\%).

CAF-1/p60 overexpression was significantly associated with shorter mean OS than CAF-1/p60 not overexpression $\left(39 \pm 4.066\right.$ vs $169.125 \pm 7.386$ months; $\chi^{2}=21.729$; $p<0.001$ ) (Fig. 4); the prognostic significance of CAF-1/p60 overexpression was stronger than that of a MF stage $\geq$ II $\left(139.586 \pm 15.656\right.$ vs $141.6 \pm 9.66$ months; $\chi^{2}=0.097 ; p=$ $0.756), \geq \mathrm{IIB}(93.645 \pm 11.006$ vs $167.556 \pm 8.467$ months; $\left.\chi^{2}=1.364 ; p=0.243\right)$, and $\geq$ III $(85.486 \pm 15.681$ vs 158.422 \pm 10.33 months; $\chi^{2}=1.624 ; p=0.203$ ) (Supplementary Figs. 1-3). On the other hand, PARP-1 overexpression was not associated with a significant decrease in the OS $(89.123 \pm 7.971 \mathrm{vs}$ $163.972 \pm 10.674$ months; $\chi^{2}=1.398 ; p<0.237$ ) (Supplementary Fig. 4); a simultaneous overexpression of PARP-1 and CAF-1/p60 was significantly associated with decreased OS $\left(40.333 \pm 4.507\right.$ vs $165.095 \pm 8.149$ months; $\chi^{2}=$ 14.916; $p<0.001$ ) (Supplementary Fig. 5), although the association was weaker compared to CAF-1/p60 as stand-alone.
Table 1 Characteristics of the patients

\begin{tabular}{|c|c|}
\hline \multicolumn{2}{|l|}{ Age $(n=64)$} \\
\hline Mean (range) & $59.4(29-96)$ \\
\hline \multicolumn{2}{|l|}{$\operatorname{Sex}(n=64)$} \\
\hline Male & $43(67.2 \%)$ \\
\hline Female & $21(32.8 \%)$ \\
\hline \multicolumn{2}{|l|}{ Stage $(n=53)$} \\
\hline I & $20(37.7 \%)$ \\
\hline - IA & $9(17 \%)$ \\
\hline$\cdot$ IB & $11(20.8 \%)$ \\
\hline II & $20(37.7 \%)$ \\
\hline • IIA & $7(13.2 \%)$ \\
\hline • IIB & $13(24.5 \%)$ \\
\hline III & $1(1.9 \%)$ \\
\hline • IIIA & $1(1.9 \%)$ \\
\hline IV & $12(22.6 \%)$ \\
\hline • IVA1 & $7(13.2 \%)$ \\
\hline - IVA2 & $5(9.4 \%)$ \\
\hline \multicolumn{2}{|l|}{ PARP-1 $(n=57)$} \\
\hline Not overexpressed & $24(42.1 \%)$ \\
\hline • $0-9 \%$ & $5(8.8 \%)$ \\
\hline$\cdot 10-19 \%$ & $1(1.8 \%)$ \\
\hline$\cdot 20-29 \%$ & $4(7 \%)$ \\
\hline • $30-39 \%$ & $13(22.8 \%)$ \\
\hline - $40-49 \%$ & $1(1.8 \%)$ \\
\hline Overexpressed & $33(57.9 \%)$ \\
\hline • $50-59 \%$ & $10(17.5 \%)$ \\
\hline • $60-69 \%$ & $6(10.5 \%)$ \\
\hline • $70-79 \%$ & $11(19.3 \%)$ \\
\hline - $80-89 \%$ & $5(8.8 \%)$ \\
\hline • $90-100 \%$ & $1(1.8 \%)$ \\
\hline \multicolumn{2}{|l|}{ CAF-1/p60 $(n=56)$} \\
\hline Not overexpressed & $41(73.2 \%)$ \\
\hline • $0-9 \%$ & $11(19.5 \%)$ \\
\hline$\cdot 10-19 \%$ & $5(8.9 \%)$ \\
\hline • $20-29 \%$ & $16(28.6 \%)$ \\
\hline • $30-39 \%$ & $8(14.3 \%)$ \\
\hline - $40-49 \%$ & $1(1.8 \%)$ \\
\hline Overexpressed & $15(26.8 \%)$ \\
\hline$\cdot 50-59 \%$ & $1(1.8 \%)$ \\
\hline • $60-69 \%$ & $4(7.1 \%)$ \\
\hline • $70-79 \%$ & $7(12.5 \%)$ \\
\hline • $80-89 \%$ & $2(3.6 \%)$ \\
\hline • $90-100 \%$ & $1(1.8 \%)$ \\
\hline \multicolumn{2}{|l|}{ Follow-up $(n=63)$} \\
\hline Mean duration (range), months & $52.9(12-180)$ \\
\hline Dead & $8(12.7 \%)$ \\
\hline Alive & $55(87.3 \%)$ \\
\hline - With disease & $28(44.4 \%)$ \\
\hline - With remission & $15(23.8 \%)$ \\
\hline$\cdot \operatorname{NOS}$ & $12(19 \%)$ \\
\hline
\end{tabular}


Fig. 1 Immunohistochemical staining for CAF-1/p60 $(\mathbf{a} \times 40 ; \mathbf{b}$ $\times 200)$ and PARP-1 $(\mathbf{c} \times 40$; $\mathbf{d} \times$ 200) in a case of patch stage MF. CAF-1/p60 resulted expressed only in $5 \%$ of the neoplastic cells while PARP-1 resulted overexpressed in $30 \%$ of neoplastic cells (both in epidermotropic that dermal lymphocytes)
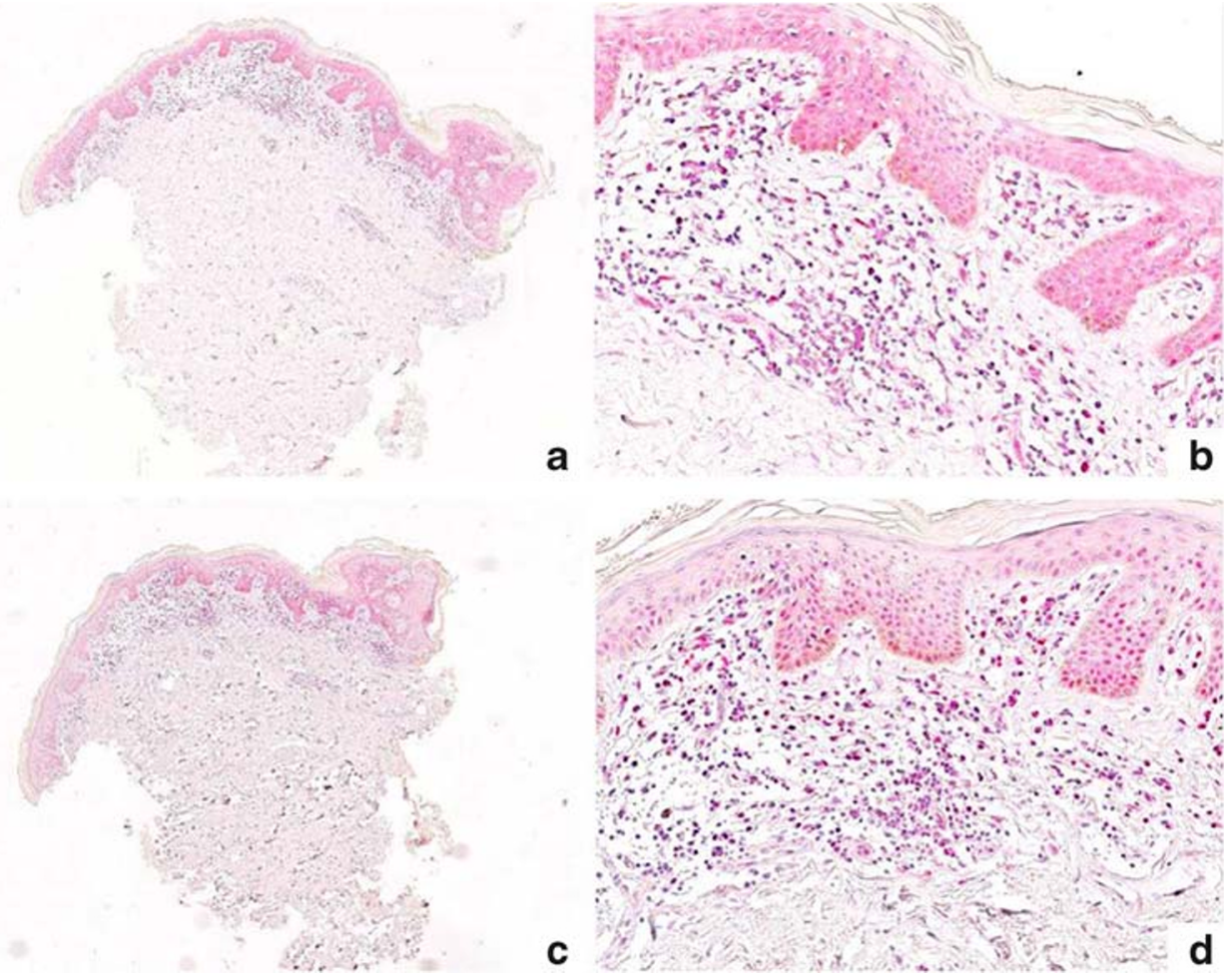

a

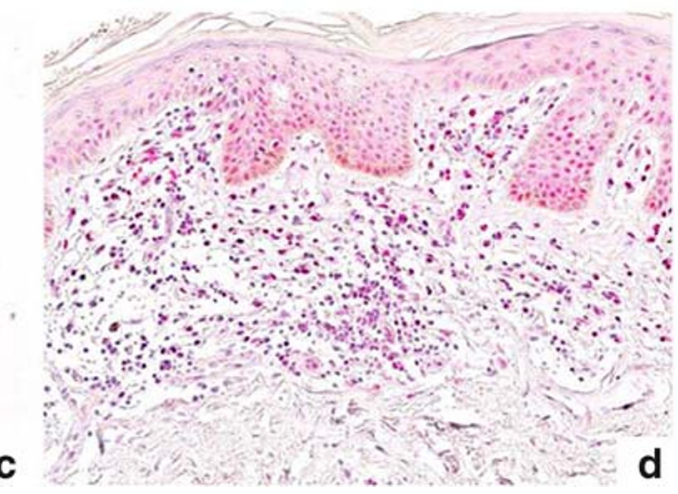

\section{Discussion}

This study showed that, in MF, PARP-1 overexpression was associated with a more advanced MF stage, while CAF-1/p60 overexpression was associated with shorter OS.
The association between PARP-1 overexpression and CAF-1/p60 overexpression was significant but did not improve the prognostic stratification.

PARP-1 is a nuclear chromatin-associated protein involved in several biological processes including cell proliferation,
Fig. 2 Immunohistochemical staining for CAF-1/p60 (a $\times 40 ; \mathbf{b}$ $\times 200)$ and PARP-1 $(\mathbf{c} \times 40$; $\mathbf{d} \times$ $200)$ in a case of plaque stage MF. CAF-1/p60 resulted overexpressed in $30 \%$ of the neoplastic cells while PARP-1 resulted overexpressed in $40 \%$ of neoplastic cells (mainly dermal lymphocytes)
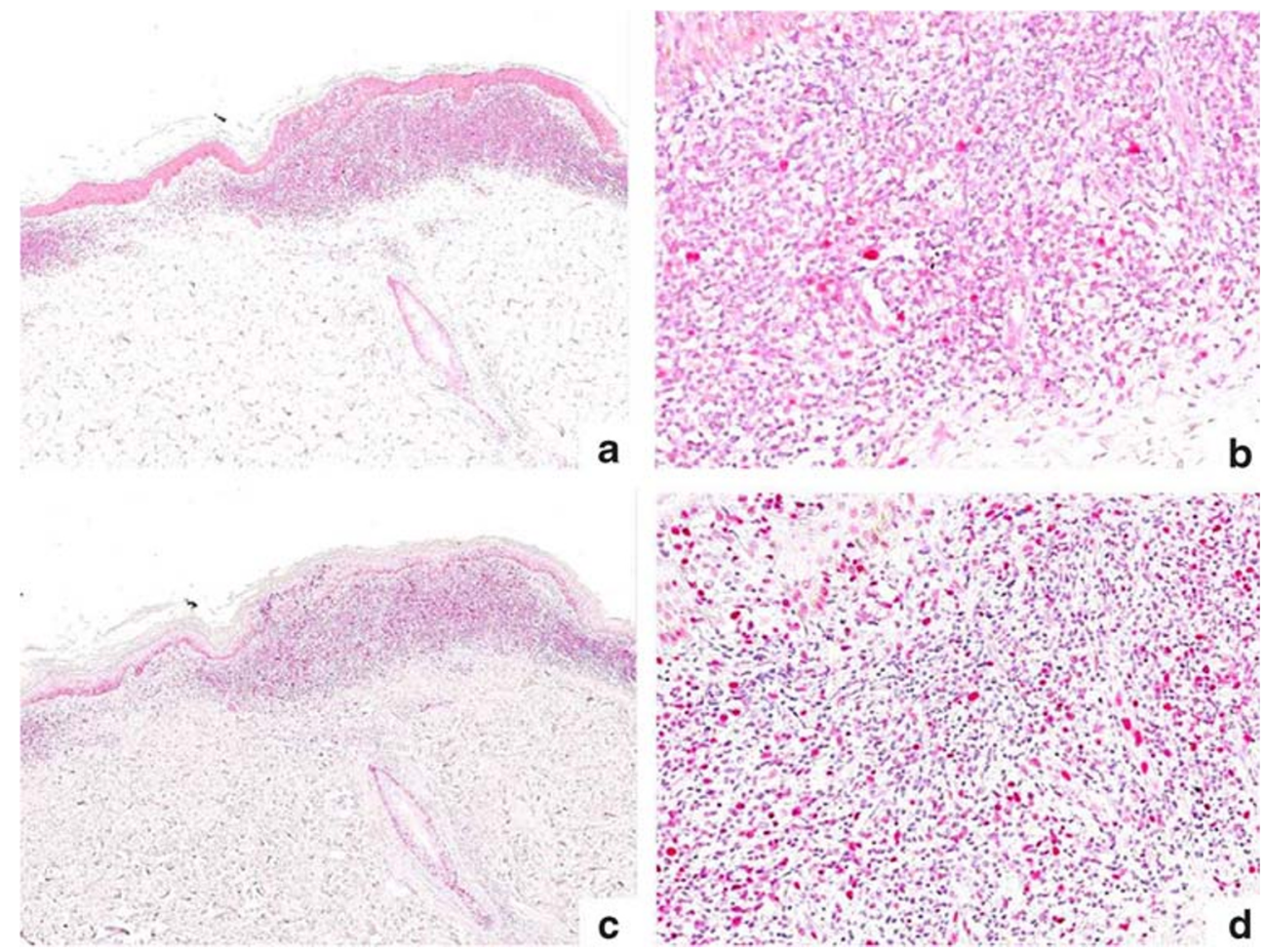
Fig. 3 Immunohistochemical staining for CAF-1/p60 $(\mathbf{a} \times 40 ; \mathbf{b}$ $\times 200)$ and PARP-1 $(\mathbf{c} \times 40$; $\mathbf{d} \times$ $200)$ in a case of tumor stage MF. CAF-1/p60 resulted overexpressed in $70 \%$ of the neoplastic cells and PARP-1 resulted overexpressed in $80 \%$ of neoplastic cells (dermal lymphocytes)
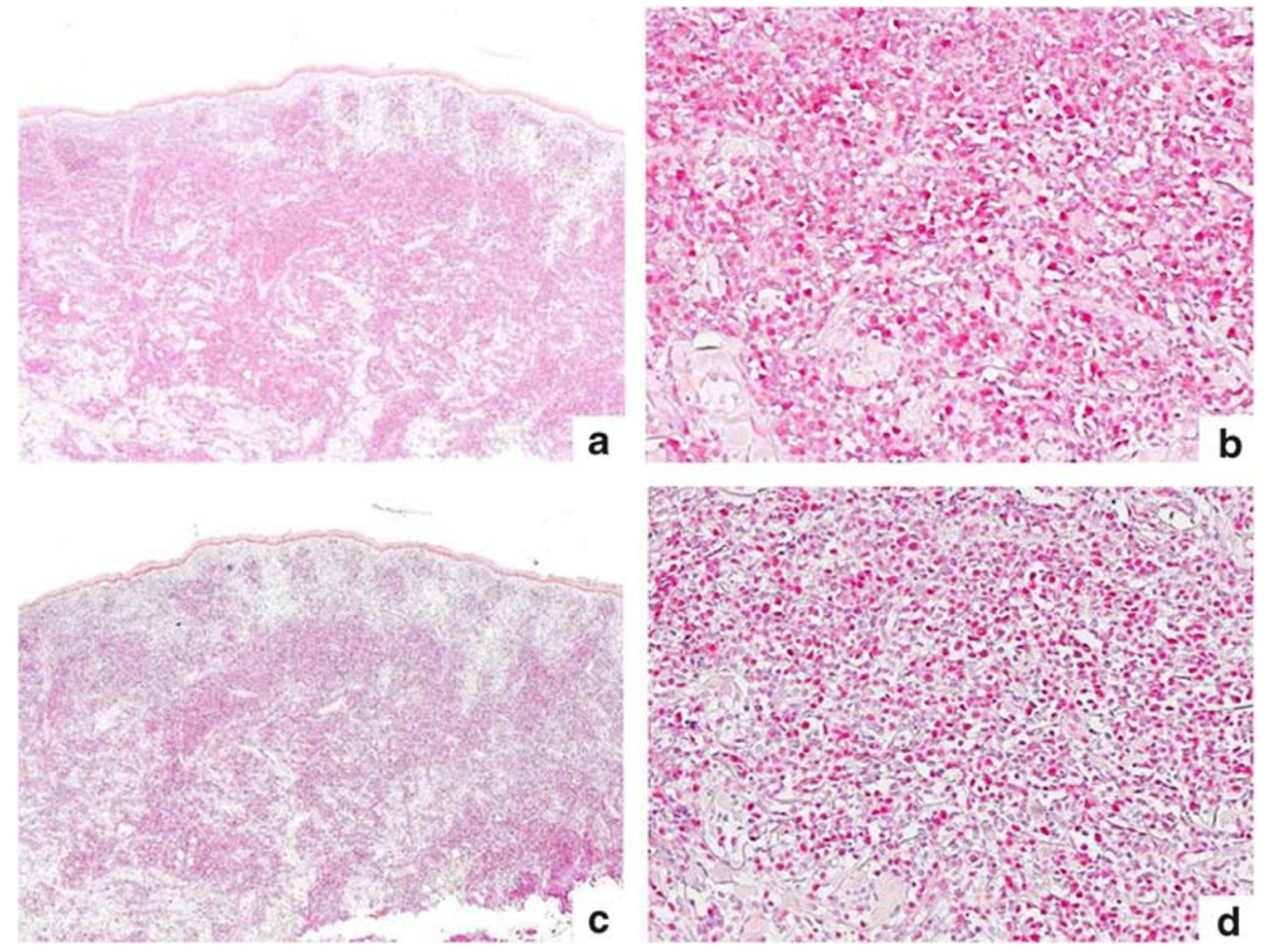

apoptosis, malignant transformation, transcriptional regulation, and DNA repair. It is essential to the base excision repair of DNA single-strand breaks (SSBs). In response to DNA damage, PARP-1 senses and binds to DNA nicks and breaks, resulting in activation of catalytic activity, causing poly ADP-ribosylation of PARP-1 itself, as well as other acceptor proteins such as histones and topoisomerases. This modification stimulates the recruitment and activity of other components of DNA repair pathways
[26]. In its absence, DNA SSBs accumulate and degenerate to DNA double-strand breaks (DSBs), which are not appropriately repaired if the BRCA pathway is deficient or dysfunctional. This is thought to explain the exquisite sensitivity to PARP inhibitors of tumors with BRCA inactivation, a concept called "synthetic lethality" $[27,28]$. In addition to well-known activity in DNA strand breaks repair, PARP-1 has a role in other cellular pathways like DNA replication, chromatin structure modification,
Fig. 4 Kaplan-Meier curves for overall survival rate in patients with mycosis fungoides according to CAF-1/p60 expression (overexpressed vs not overexpressed)

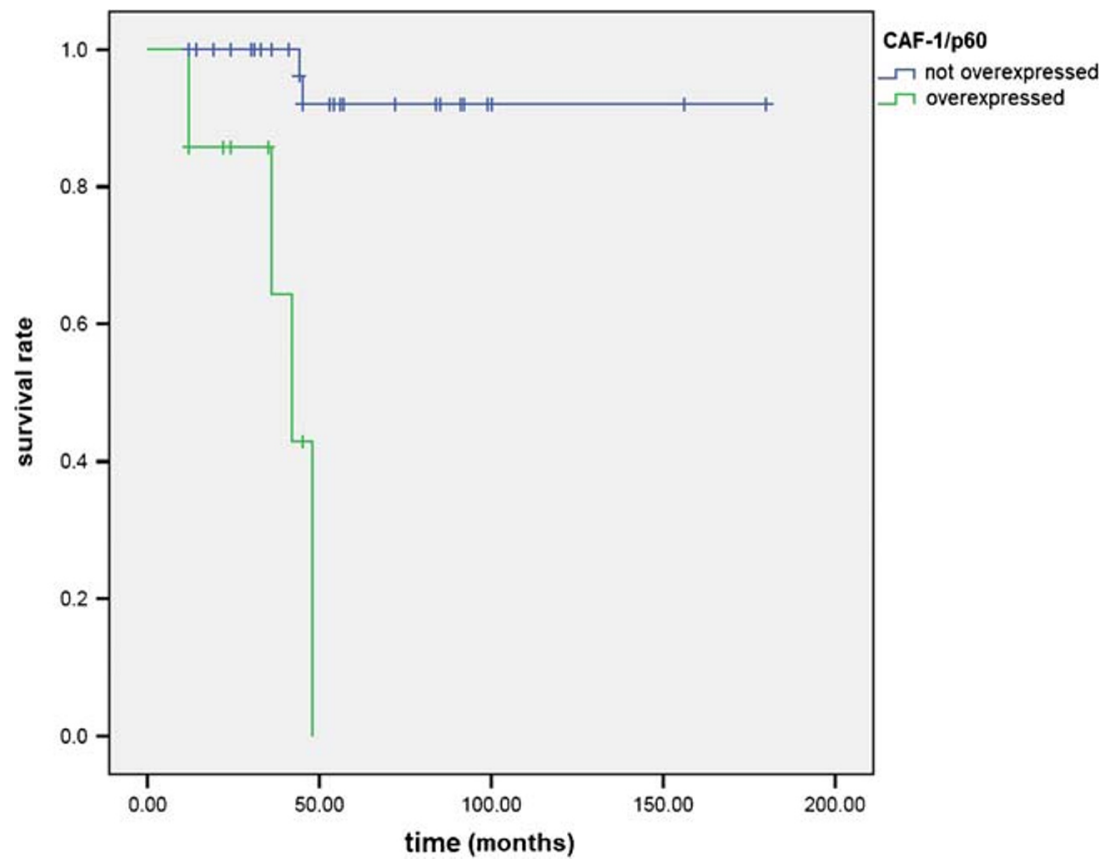


and cell cycle control. In particular, PARP-1 seems to have a role in stabilization and restart of the arrested replication fork and can facilitate nucleosome disassembly by histone PARylation resulting in chromatin relaxation facilitating DNA repair through the action of large protein complexes, such as the molecular chaperone chromatin assembly factor-1 (CAF1) $[27,29-31]$. CAF-1 is a histone chaperone conserved from yeast to human cells involved in the deposition of newly synthesized $\mathrm{H} 3-\mathrm{H} 4$ tetramers. CAF-1 interacts with proliferating cell nuclear antigen (PCNA), a DNA polymerase clamp for DNA polymerases, and co-localizes with PCNA at replication foci in the early $\mathrm{S}$ phase of the cell cycle, consistent with the idea that CAF-1 is recruited to DNA replication forks through its interaction with PCNA for nucleosome assembly [32].

PARP-1 and CAF-1/p60 nuclear proteins crosstalk with several molecular pathways involved in histone acetylation. The poly ADP-ribosylation of histones effectively functions like acetylation, maintaining chromatin nucleosomes in a fully relaxed, transcriptionally active state. Either PARP-1 [50] or CAF-1/p60 [43] overexpression has been reported in multiple types of cancer, and this has been related to histopathological grade and/or adverse clinical behavior. Their expression could help tumor cells to withstand genotoxic stress, by increasing their resistance to DNA-damaging agents and may result in radio-resistance and chemo-resistance $[43,50]$.

In this study, we found no prognostic value for PARP-1 expression in MF, as it was not associated with OS. This result does not confirm that reported in the previously published study by Lemchak et al., which showed an association between PARP-1 overexpression and MF progression. However, that study evaluating only 19 patients with MF represented a very preliminary assessment. Interestingly, Lemchak et al. showed that PARP inhibitors had a cytotoxic effect on Sezary cells, suggesting a possible use of PARP inhibitors in MF [25].

The results of our study do not contrast with such a possibility. In fact, we found that PARP-1 overexpression was significantly associated with a MF stage $>$ II, providing a rationale for the use of PARP-1 inhibitors in advanced stages of MF.

Unlike PARP-1, we did not find an association between the MF stage and CAF-1/p60. Our result showed that CAF-1/p60 expression was a significant prognostic factor for the OS of patients with MF. CAF-1/p60 overexpression was indeed associated with a shorter OS more strongly than the MF stage. Remarkably, this result is consistent with previous studies focused on breast, oral, prostate, and salivary gland carcinomas, as well as in skin melanoma [44-48], strengthening the possible role of CAF-1/p60 as a "multi-tumoral" prognostic marker. These findings, although preliminary, may be a rationale for the development of targeted therapies against CAF-1/p60.

We previously demonstrated that a simultaneous overexpression of PARP-1 and CAF-1/p60 was a still more reliable prognosticator of poor outcome compared to CAF-1/p60 alone in oral carcinoma [51]. This finding was not confirmed in MF. Although a significant association between the overexpression of the two proteins was found, the simultaneous overexpression of PARP-1 and CAF-1/p60 appeared less reliable than CAF-1/ p60 alone in predicting the risk of death in MF. However, given the association of PARP-1 and CAF-1/p60 with advanced stages and poor prognosis, respectively, it is possible to hypothesize that a combination of PARP inhibitors and anti-CAF-1/ p60 targeted therapy might be effective in MF. In this regard, we previously showed that the inhibition of CAF-1/p60 made cancer cells more susceptible to PARP inhibitors [51].

Given the low number of patients assessed, our results should be considered preliminary. In fact, there were only few patients for each stage (e.g., only one patient was at stage III), making a correlation between protein expression and stage difficult. We believe our results are encouraging for further and larger studies in this field.

\section{Conclusion}

In MF, PARP-1 overexpression is associated with advanced stage, while CAF-1/p60 is associated with decreased OS, resulting potentially useful as a prognostic marker. On this account, it is reasonable to hypothesize that PARP-1 inhibitors might be effective in advanced MF and that a targeted therapy against CAF-1/p60 might have a role as well. Further studies are encouraged in this regard.

Authors' contributions M.M.: study conception, study protocol, data collection, literature review, pathology review, manuscript revision, supervision; A.T.: study protocol, data collection, manuscript preparation, manuscript revision; S.V.: study conception, study protocol, data collection, manuscript preparation; D.R.: study protocol, data collection, pathology review, manuscript preparation; E.S.: study protocol, pathology review, manuscript revision, supervision; C.A.: study protocol, data collection, pathology review, manuscript revision; C.B.: study protocol, data collection, manuscript preparation; A.B.: data collection, clinical review, manuscript revision; A.P.: data collection, clinical review, manuscript revision; M.P.: study protocol, data collection, clinical review, manuscript revision; F.P.: study protocol, clinical review, manuscript revision, supervision; S.S.: study conception, study protocol, manuscript revision, supervision.

Funding Open access funding provided by Università degli Studi di Napoli Federico II within the CRUI-CARE Agreement

\section{Compliance with ethical standards}

The study was performed according to the guidelines of the Institutional Ethics Committee, which, in agreement with the Italian law, with reference to the topics of the current research, do not ask for the Ethical Committee approval, and, according to the Declaration of Helsinki, requires, for studies based only on retrospective analyses on routine archival formalin-fixed, paraffin-embedded tissue a written informed consent from the living patient, following the indication of Italian DLgs no. 196/ 03 (Codex on Privacy) at the time of surgery. 
Conflict of interest The authors declare that they have no conflict of interest.

Open Access This article is licensed under a Creative Commons Attribution 4.0 International License, which permits use, sharing, adaptation, distribution and reproduction in any medium or format, as long as you give appropriate credit to the original author(s) and the source, provide a link to the Creative Commons licence, and indicate if changes were made. The images or other third party material in this article are included in the article's Creative Commons licence, unless indicated otherwise in a credit line to the material. If material is not included in the article's Creative Commons licence and your intended use is not permitted by statutory regulation or exceeds the permitted use, you will need to obtain permission directly from the copyright holder. To view a copy of this licence, visit http://creativecommons.org/licenses/by/4.0/.

\section{References}

1. Willemze R, Jaffe ES, Burg G, Cerroni L, Berti E, Swerdlow SH, Ralfkiaer E, Chimenti S, Diaz-Perez JL, Duncan LM, Grange F, Harris NL, Kempf W, Kerl H, Kurrer M, Knobler R, Pimpinelli N, Sander C, Santucci M, Sterry W, Vermeer MH, Wechsler J, Whittaker S, Meijer CJ (2005) WHO-EORTC classification for cutaneous lymphomas. Blood 105:3768-3785. https://doi.org/10. 1182/blood-2004-09-3502

2. Swerdlow SH et al. (2017) WHO classification of tumors of haematopoietic and lymphoid tissues. Lyon, France. World Health Organization Calssification of Tumors of Haematopoietic and Lymphoid Tissue. doi:https://doi.org/10.1017/ CBO9781107415324.004

3. Trautinger F, Eder J, Assaf C, Bagot M, Cozzio A, Dummer R, Gniadecki R, Klemke CD, Ortiz-Romero PL, Papadavid E, Pimpinelli N, Quaglino P, Ranki A, Scarisbrick J, Stadler R, Väkevä L, Vermeer MH, Whittaker S, Willemze R, Knobler R (2017) European organisation for research and treatment of cancer consensus recommendations for the treatment of mycosis fungoides/Sézary syndrome - update 2017. Eur J Cancer 77:57-74

4. Korgavkar K, Xiong M, Weinstock M (2013) Changing incidence trends of cutaneous T-cell lymphoma. JAMA Dermatol 149(11): 1295-1299

5. Su C, Nguyen KA, Bai HX et al (2017) Racial disparity in mycosis fungoides: an analysis of 4495 cases from the US National Cancer Database. J Am Acad Dermatol 77(3):497-502 e2

6. Fink-Puches R, Chott A, Ardigo M, Simonitsch I, Ferrara G, Kerl H, Cerroni L (2004) The spectrum of cutaneous lymphomas in patients less than 20 years of age. Pediatr Dermatol 21:525-533. https://doi.org/10.1111/j.0736-8046.2004.21500.x

7. Virmani P, Myskowski PL, Pulitzer M (2016) Unusual variants of mycosis fungoides. Diagn Histopathol (Oxf) 22(4):142-151

8. Fabbrocini G, Mazzella C, Cantelli M, Baldo A, Russo D, de Rosa G, Monfrecola G (2018) Reflectance confocal microscopy as new diagnostic tool in folliculotropic mycosis fungoides. Skin Appendage Disord 4(2):118-121

9. Mascolo M, Romano MF, Ilardi G, Romano S, Baldo A, Scalvenzi M, Argenziano G, Merolla F, Russo D, Varricchio S, Pagliuca F, Russo M, Ciancia G, de Rosa G, Staibano S (2018) Expression of FK506-binding protein 51 (FKBP51) in mycosis fungoides. J Eur Acad Dermatol Venereol 32(5):735-744

10. Scarisbrick JJ, Kim YH, Whittaker SJ, Wood GS, Vermeer MH, Prince HM, Quaglino P (2014) Prognostic factors, prognostic indices and staging in mycosis fungoides and Sézary syndrome: where are we now? Br J Dermatol 170(6):1226-1236
11. Benner MF, Jansen PM, Vermeer MH, Willemze R (2012) Prognostic factors in transformed mycosis fungoides: a retrospective analysis of 100 cases. Blood. 119(7):1643-1649

12. Larocca C, Kupper T (2019) Mycosis fungoides and Sézary syndrome: an update. Hematol Oncol Clin North Am 33(1):103-120

13. Hanel W, Briski R, Ross CW, Anderson TF, Kaminski MS, Hristov AC, Wilcox RA (2016) A retrospective comparative outcome analysis following systemic therapy in mycosis fungoides and Sezary syndrome. Am J Hematol 91(12):E491-E495

14. Wilcox RA (2018) Cutaneous B-cell lymphomas: 2019 update on diagnosis, risk stratification, and management. Am J Hematol 93(11):1427-1430

15. Hughes $\mathrm{CF}$, Khot A, McCormack $\mathrm{C}$ et al (2015) Lack of durable disease control with chemotherapy for mycosis fungoides and Sézary syndrome: a comparative study of systemic therapy. Blood. 125(1):71-81

16. Duarte RF, Canals C, Onida F, Gabriel IH, Arranz R, Arcese W, Ferrant A, Kobbe G, Narni F, Deliliers GL, Olavarría E, Schmitz N, Sureda A (2010) Allogeneic hematopoietic cell transplantation for patients with mycosis fungoides and Sézary syndrome: a retrospective analysis of the Lymphoma Working Party of the European Group for Blood and Marrow Transplantation. J Clin Oncol 28(29):4492-4499

17. Tan RS, Butterworth CM, McLaughlin H, Malka S, Samman PD (1974) Mycosis fungoides-a disease of antigen persistence. Br J Dermatol 91(6):607-616

18. Wohl Y, Tur E (2007) Environmental risk factors for mycosis fungoides. Curr Probl Dermatol 35:52-64

19. McGirt LY, Adams CM, Baerenwald DA, Zwerner JP, Zic JA, Eischen CM (2014) miR-223 regulates cell growth and targets proto-oncogenes in mycosis fungoides/cutaneous T-cell lymphoma. J Invest Dermatol 134(4):1101-1107

20. Quaglino P, Pimpinelli N, Berti E, Calzavara-Pinton P, Alfonso Lombardo G, Rupoli S, Alaibac M, Bottoni U, Carbone A, Fava P, Fimiani M, Mamusa AM, Titli S, Zinzani PL, Bernengo MG, on behalf of the Gruppo Italiano Linfomi Cutanei (GILC) (2012) Time course, clinical pathways, and long-term hazards risk trends of disease progression in patients with classic mycosis fungoides: a multicenter, retrospective follow-up study from the Italian Group of Cutaneous Lymphomas. Cancer. 118(23):5830-5839

21. Lindahl LM, Besenbacher S, Rittig AH, Celis P, Willerslev-Olsen A, Gjerdrum LMR, Krejsgaard T, Johansen C, Litman T, Woetmann A, Odum N, Iversen L (2018) Prognostic miRNA classifier in early-stage mycosis fungoides: development and validation in a Danish nationwide study. Blood. 131(7):759-770

22. de Masson A, O'Malley JT, Elco CP et al (2018) High-throughput sequencing of the $\mathrm{T}$ cell receptor $\beta$ gene identifies aggressive earlystage mycosis fungoides. Sci Trans1 Med 10(440):eaar5894

23. Wehkamp U, Weichenthal M, Egberts F, Schwarz T, Klapper W, Oschlies I (2018) Clinically defined subgroups of mycosis fungoides display differing histopathological features at initial biopsy. Leuk Lymphoma 59(12):2871-2879

24. Scarisbrick JJ, Prince HM, Vermeer MH, Quaglino P, Horwitz S, Porcu P, Stadler R, Wood GS, Beylot-Barry M, Pham-Ledard A, Foss F, Girardi M, Bagot M, Michel L, Battistella M, Guitart J, Kuzel TM, Martinez-Escala ME, Estrach T, Papadavid E, Antoniou C, Rigopoulos D, Nikolaou V, Sugaya M, Miyagaki T, Gniadecki R, Sanches JA, Cury-Martins J, Miyashiro D, Servitje O, Muniesa C, Berti E, Onida F, Corti L, Hodak E, Amitay-Laish I, Ortiz-Romero PL, Rodríguez-Peralto JL, Knobler R, Porkert S, Bauer W, Pimpinelli N, Grandi V, Cowan R, Rook A, Kim E, Pileri A, Patrizi A, Pujol RM, Wong H, Tyler K, Stranzenbach R, Querfeld C, Fava P, Maule M, Willemze R, Evison F, Morris S, Twigger R, Talpur R, Kim J, Ognibene G, Li S, Tavallaee M, Hoppe RT, Duvic M, Whittaker SJ, Kim YH (2015) Cutaneous lymphoma international consortium study of outcome in advanced 
stages of mycosis fungoides and Sézary syndrome: effect of specific prognostic markers on survival and development of a prognostic model. J Clin Oncol 33(32):3766-3773

25. Lemchak D, Banerjee S, Digambar SS, Hood BL, Conrads TP, Jedrych J, Geskin L, Akilov OE (2018) Therapeutic and prognostic significance of PARP-1 in advanced mycosis fungoides and Sezary syndrome. Exp Dermatol 27(2):188-190

26. Amé JC, Spenlehauer C, de Murcia G (2004) The PARP superfamily. Bioessays. 26(8):882-893

27. Bryant HE, Schultz N, Thomas HD, Parker KM, Flower D, Lopez E, Kyle S, Meuth M, Curtin NJ, Helleday T (2005) Specific killing of BRCA2-deficient tumours with inhibitors of poly(ADP-ribose) polymerase [published correction appears in Nature. 2007 May 17;447(7142):346]. Nature. 434(7035):913-917

28. Farmer H, McCabe N, Lord CJ, Tutt ANJ, Johnson DA, Richardson TB, Santarosa M, Dillon KJ, Hickson I, Knights C, Martin NMB, Jackson SP, Smith GCM, Ashworth A (2005) Targeting the DNA repair defect in BRCA mutant cells as a therapeutic strategy. Nature. 434(7035):917-921

29. Yang L, Huang K, Li X, du M, Kang X, Luo X, Gao L, Wang C, Zhang Y, Zhang C, Tong Q, Huang K, Zhang F, Huang D (2013) Identification of poly(ADP-ribose) polymerase-1 as a cell cycle regulator through modulating $\mathrm{Sp} 1$ mediated transcription in human hepatoma cells. PLoS One 8(12):e82872

30. Ray Chaudhuri A, Hashimoto Y, Herrador R, Neelsen KJ, Fachinetti D, Bermejo R, Cocito A, Costanzo V, Lopes M (2012) Topoisomerase I poisoning results in PARP-mediated replication fork reversal. Nat Struct Mol Biol 19(4):417-423

31. Rouleau M, Aubin RA, Poirier GG (2004) Poly(ADP-ribosyl)ated chromatin domains: access granted. J Cell Sci 117(Pt 6):815-825

32. Volk A, Crispino JD (2015) The role of the chromatin assembly complex (CAF-1) and its p60 subunit (CHAF1b) in homeostasis and disease. Biochim Biophys Acta 1849(8):979-986

33. Ozanne SE, Constância M (2007) Mechanisms of disease: the developmental origins of disease and the role of the epigenotype. Nat Clin Pract Endocrinol Metab 3(7):539-546

34. Ehrenhofer-Murray AE (2004) Chromatin dynamics at DNA replication, transcription and repair. Eur J Biochem 271(12):2335-2349

35. Verreault A, Kaufman PD, Kobayashi R, Stillman B (1996) Nucleosome assembly by a complex of CAF-1 and acetylated histones H3/H4. Cell. 87(1):95-104

36. Zhu Q, Wani G, Arab HH, El-Mahdy MA, Ray A, Wani AA (2009) Chromatin restoration following nucleotide excision repair involves the incorporation of ubiquitinated $\mathrm{H} 2 \mathrm{~A}$ at damaged genomic sites. DNA Repair (Amst) 8(2):262-273

37. Tagami H, Ray-Gallet D, Almouzni G, Nakatani Y (2004) Histone H3.1 and H3.3 complexes mediate nucleosome assembly pathways dependent or independent of DNA synthesis. Cell. 116(1):51-61

38. Ramirez-Parra E, Gutierrez C (2007) The many faces of chromatin assembly factor 1 . Trends Plant Sci 12(12):570-576

39. Gaillard PHL, Martini EM, Kaufman PD, Stillman B, Moustacchi E, Almouzni G (1996) Chromatin assembly coupled to DNA repair: a new role for chromatin assembly factor I. Cell. 86(6):887-896
40. Linger JG, Tyler JK (2007) Chromatin disassembly and reassembly during DNA repair. Mutat Res 618(1-2):52-64

41. Verger A, Crossley M (2004) Chromatin modifiers in transcription and DNA repair. Cell Mol Life Sci 61(17):2154-2162

42. Polo SE, Theocharis SE, Klijanienko J, Savignoni A, Asselain B, Vielh P, Almouzni G (2004) Chromatin assembly factor-1, a marker of clinical value to distinguish quiescent from proliferating cells. Cancer Res 64(7):2371-2381

43. Polo SE, Theocharis SE, Grandin L, Gambotti L, Antoni G, Savignoni A, Asselain B, Patsouris E, Almouzni G (2010) Clinical significance and prognostic value of chromatin assembly factor-1 overexpression in human solid tumours. Histopathology. 57(5):716-724

44. Mesolella M, Iorio B, Landi M, Cimmino M, Ilardi G, Iengo M, Mascolo M (2017) Overexpression of chromatin assembly factor-1/ p60 predicts biological behaviour of laryngeal carcinomas. L'espressività della proteina CAF-1 p60 come fattore prognostico nei carcinomi laringei. Acta Otorhinolaryngol Ital 37(1):17-24

45. Mascolo M, Ilardi G, Merolla F, Russo D, Vecchione ML, de Rosa G, Staibano S (2012) Tissue microarray-based evaluation of chromatin assembly factor-1 (CAF-1)/p60 as tumour prognostic marker. Int J Mol Sci 13(9):11044-11062

46. Mascolo M, Ilardi G, Romano MF, Celetti A, Siano M, Romano S, Luise C, Merolla F, Rocco A, Vecchione ML, de Rosa G, Staibano S (2012) Overexpression of chromatin assembly factor-1 p60, poly(ADP-ribose) polymerase 1 and nestin predicts metastasizing behaviour of oral cancer. Histopathology. 61(6):1089-1105

47. Staibano S, Mascolo M, Rocco A, Lo Muzio L, Ilardi G, Siano M, Pannone G, Vecchione ML, Nugnes L, Califano L, Zamparese R, Bufo P, de Rosa G (2011) The proliferation marker chromatin assembly factor- 1 is of clinical value in predicting the biological behaviour of salivary gland tumours. Oncol Rep 25(1):13-22

48. Mascolo M, Vecchione ML, Ilardi G, Scalvenzi M, Molea G, di Benedetto M, Nugnes L, Siano M, de Rosa G, Staibano S (2010) Overexpression of chromatin assembly factor-1/p60 helps to predict the prognosis of melanoma patients. BMC Cancer 10:63

49. Staibano S, Mascolo M, Mancini FP, Kisslinger A, Salvatore G, di Benedetto M, Chieffi P, Altieri V, Prezioso D, Ilardi G, de Rosa G, Tramontano D (2009) Overexpression of chromatin assembly factor-1 (CAF-1) p60 is predictive of adverse behaviour of prostatic cancer. Histopathology. 54(5):580-589

50. Ossovskaya V, Koo IC, Kaldjian EP, Alvares C, Sherman BM (2010) Upregulation of Poly (ADP-Ribose) Polymerase-1 (PARP1) in Triple-Negative Breast Cancer and Other Primary Human Tumor Types. Genes Cancer 1(8):812-821

51. Morra F, Merolla F, Picardi I et al (2019) CAF-1 subunits levels suggest combined treatments with PARP-inhibitors and ionizing radiation in advanced HNSCC. Cancers (Basel). 11(10):1582

Publisher's note Springer Nature remains neutral with regard to jurisdictional claims in published maps and institutional affiliations. 